\title{
Discussions on Pagan Theology in the Academia and in the Pagan Community
}

\author{
Stanislav Panin \\ Lecturer, D. Mendeleyev University of Chemical Technology of Russia, Moscow, Russia \\ Email: stanislav_panin@gmx.com
}

\author{
Doi:10.5901/mjss.2015.v6n3s1p602
}

\begin{abstract}
A concept of Pagan Theology has been producing a number of discussions throughout the last decade and particularly in the last few years both inside and outside Pagan community. In this paper, the author analyzes three aspects of the phenomenon of Pagan Theology and discussions emerged around it. The first aspect is the genesis of the idea of Pagan Theology. It includes an examination of academic and religious roots of this research programme. The second aspect is a view on Pagan Theology from the perspective of the academia. While for some scholars Pagan Theology appears to be a legitimate field of study and/or research programme in Pagan Studies, others describe it is an attempt of Pagan intervention in the academia. Finally, the third aspect is a discussion on Pagan Theology emerged among Pagans, whose reflections of this topic are very ambiguous too. In spite of this fact, the author concludes that the idea of Pagan Theology was a necessary stage of development, both in the conceptualization of contemporary Paganism itself and in Pagan Studies at the same time.
\end{abstract}

Keywords: Pagan Theology, Pagan Studies, Paganism

\section{Introduction}

A concept of Pagan Theology that denotes studies aimed to find and describe the main features of Paganism as a whole is a highly controversial research programme in Pagan Studies, which took its shape in the beginning of the millennium. Debates around this concept are, from my point of view, very important for scholars of new religions and esotericism, because these debates can show us different ways to understand Religious and Esoteric Studies per se as well as show us a number of issues in these fields. They also help us to understand deeper the plurality of opinions existing among Pagans themselves in understanding of what Paganism is and what should be the future of its relations with the academia and with Western rationality in general.

\section{Literature Review}

A concept of "Pagan Theology" is usually associated with Michael York's book Pagan Theology: Paganism as a World Religion (York, 2003). In the book, the author tries to describe some aspects of Weltanschauung and behavior that, as he believes, defines the common ground for all Pagan movements. C. Kraemer used and developed the idea in her book Seeking the Mystery: An Introduction to Pagan Theologies (Kraemer, 2012). Its title with plural form "Theologies" instead of "Theology" shows the accent on plurality and undogmatic essence of Pagan traditions. In contrast with York's book, Seeking the Mystery is a book addressed not to researchers, but rather to insiders participating in courses dedicated to Pagan Theology. The book definitely indicates a transformation of York's research programme into a specific discipline that is in many senses beyond the domain of Religious Studies. On the other hand, the book includes extremely valuable emic materials for further studies of Paganism and an interesting attempt of summarization of Pagan beliefs that can be useful for scholars in their studies of Paganism.

The concept of Pagan Theology was in a scope of a number of discussions throughout the last decade and particularly in the last few years both inside and outside the Pagan community. In 2012 and 2013 a related discussion of Pagan Studies emerged with a critical publication of M. Davidsen in Method and Theory in the Study of Religion (Davidsen, 2012) followed by answers published in Pomegranate by E. D. White (2012) and M. York (2013). The discussion had a wide resonance and moved from the pages of academic publications into the Internet. Particularly, M. Harrington, whose works were criticized in Davidsen's article, answered him on her page at academia.edu. The topic was also in a scope of discussions on several academic conferences, for example, during a Conference on Current Pagan Studies 2013 in Claremont (Pitzl-Waters, 2013). 


\section{Analysis}

In this paper, I will try to focus on three important aspects in discussions related to Pagan Theology which are the roots of Pagan Theology and the reactions of the academia and of Pagans on this phenomenon.

\subsection{The roots of the Pagan Theology}

I believe that the birth of the Pagan Theology is reflecting the development of Pagan community itself, or the development of contemporary Paganism as a religion. All religions in their development go through similar states. Almost every religion emerges as a small, esoteric community with a charismatic leader (or leaders), who has a direct mystical experience, and a group of his or her followers. In very ancient times, such a function could belong to a shaman or to the chieftain of a tribe. However, it was the same for Buddhism or for Christianity as well as it is for contemporary Wicca created by a group leading by G. Gardner and, for some measure, by D. Valiente. If a doctrine then becomes popular, it gets more and more followers, and so an esoteric group gives a birth to a new religion. A religion with quite a number of followers and almost no institutional pressure can be undogmatic one, because there is nobody to control what people believe in and how they behave. In such a situation, a wide diversity of currents emerges, like in the early Christianity, for example. It is a good, fertile time; however, it leads to a crisis of identity when people simply cannot understand what does it means to be a follower of this religion. An explanation needed, be it common rituals, common myth or common beliefs. On the other hand, some people involved in this religion, those of the intellectual type, tries to rationalize it. This gives a birth to theology that can be theology of different types: philosophical theology of the Ancient Greek authors is prominently different from Christian or Muslim theology, but both of them are attempts of rationalization of religious beliefs. A level of dogmatism can differs from religion to religion, from country to country, from age to age. For example, Ancient Greeks who were rather liberal about religious beliefs still thought that every member of their community should believe in gods and participate in religious rituals, whereas how exactly did he or she believe in gods was his or her own duty. Nevertheless, when Socrates was condemned to death accusations against him included an invention of new gods, while Anaxagoras leaved Athens because of accusation in atheism for his philosophical ideas. Thus, we can say that, although the Greeks were generally rather liberal about religion, there were some questions where you could not ignore common beliefs, and so there was a type of Ancient Greek "credo". In any case, every religion that reached an advanced stage of development gives birth for a type of theology which can be more dogmatic or less dogmatic in accordance with the frame of mind of the time and of the territory where it appeared. Paganism is not an exclusion, so one can ask if its amorphous form that we see today really an essential feature of Pagan Weltanschauung or just an attribute of its current state of development.

Besides internal reasons described above, there was an important external, social reason for the emergence of Pagan Theology. We know that theologies of "traditional" religions, first of all, Christian Theology is a part European and American education system for centuries as well as Philosophy of Religion with its attempts to create a rational foundation for religion (for example, in the works of British philosopher R. Swinburne). This creates an important precedent: if one kind of theology, say Christian Theology, regarded as academic discipline why should not others be regarded the same way? Therefore, we can say with no doubts that the very fact of the existence of Christian Theology itself has given birth to the idea of Pagan Theology. Another social reason supports it: a need in "religious specialists", like priests, who will perform different religious ceremonies and pastoral services and will have a verified qualification to perform it. Nobody wants to be fooled and misguided by a person who know nothing about his or her religion but pretend to be a priest. Therefore, we usually want to be sure that the person we talk to has qualification needed, and proper education is a good indicator of it. Because of these reasons, a Pagan Theology is not only a research programme in Religious/Pagan Studies but it also tends to institutionalize itself as an independent discipline.

For now, I have described Pagan Theology as a phenomenon which belongs mostly to the Pagan community, but Pagan Theology has emerged not only from it, but also from the academia. Pagan Theology has emerged in Britain and in the USA and it is by no means a matter of chance. Academic roots of Pagan Theology belong to the Anglo-American tradition of scholarship in Religious and Esoteric Studies, where an influence of "religionism" of Eranos transmitted through M. Eliade and phenomenology of religion brought in the USA by J. Wach has very prominent significance. The former aimed at "exploring historical sources in search of what is eternal and universal" (Hanegraaff, 2012). The latter tried to "perceive religion on its own terms, or essence", "use a comparative approach to reveal what is essential in religion", "maintaining a proper understanding or empathy of religion to prevent a reduction of religion to another plane of explanation" (Phenomenology of Religion, 2006). Eliade and Wach together with philosopher and theologian C. Tillich formed a group known as the Chicago school of Religious Studies influenced American scholarship in the field of 
Religious and Esoteric Studies very prominently. The main idea of these scholars was to describe the universal elements that are essential for every religion, the idea that obviously influenced the Pagan Theology looking for such common elements in different pagan traditions. Therefore, it can be regarded as a particular incarnation of this research programme. On the other hand, the History of Ideas was another force that prominently influenced Anglo-American scholarship in the field. The creation of the History of Ideas is usually associated with A. O. Lovejoy, but the concept of the History of Ideas has also the prominent resemblance with ideas of German philosopher E. Cassirer who worked in the USA in 1941 - 1945. In the study of esotericism, L. Thorndike adopted this approach and then famous British scholar F. Yates, who was influenced by Thorndike's works (Yates, 1964). Thorndike wrote about magic: "Some may think it strange that I associate magic so closely with the history of thought $<. . .>$ The exact meaning of the word, "magic," was a matter of much uncertainty even in classical and medieval times, as we shall see. There can be no doubt, however, that it was then applied not merely to an operative art, but also to a mass of ideas or doctrine, and that it represented a way of looking at the world" (Thorndike, 1923). If we replace here the word "magic" with the word "Paganism", we can easily understand that the approach used by York derives from this tradition. William James' ideas in Epistemology and Philosophy of Religion were one more important component of Anglo-American tradition in Religious and Esoteric Studies. His works brought an accent on religious experience and critical attitude towards to classical empiricism and evidentialism in the field.

Therefore, we can see how the concept reflects American and British realities, including those related to specifics of Anglo-American scholarship in Religious and Esoteric Studies. On the other hand, Pagan Theology does not belong only to these countries. Both Pagans and scholars from other countries demonstrate an interest in this concept. At least, after publication of my first paper dedicated to this topic, I have received its appreciation from different countries marking the topic as interesting and important. We can also see very similar tendencies related to conceptualization of Pagan Theology in other countries, for example, in Russia, where this term is usually associated with Russian Pagan current named "Rodnoverie" (Родновериe). If you try to search "Pagan Theology" in Russian on the Internet, you will find a number of entries written by Russian Pagans. The term itself came into Russian Paganism not from the Western sources, but rather from the works of famous Soviet scholar B. A. Rybakov who used it to describe the religious ideas of ancient Slavs, particularly when we writes about Zbruch Idol (Rybakov, 1980) and about Pagan priests (Rybakov, 1987). Rybakov is a very popular author among Russian Pagans and his influence was as prominent as those of M. Murray on G. Gardner. That is why we cannot be surprised when we find out that the concept of Pagan Theology can find a fertile ground in Russia. While Rybakov wrote mostly about ancient Russian Paganism and used this term to describe rather a type of ancient Weltanschauung than a particular research programme or discipline, contemporary Pagans in Russia use the term to describe Pagan beliefs in general and rationalization of these beliefs. On Russian Pagan site "Bujan", for instance, there is an article entitled Questions and Answers about Paganism, where we can read a statement that "Paganism is a world religion" (Questions and Answers, 2012). I believe that the authors of the article have not ever read the York's book, at least they do not mention it in their articles, but their statement is the same as in the title of the book. That shows us the process of creation of Pagan Theology is not only an American or British phenomenon, but also a phenomenon that belongs to contemporary Paganism in general.

\subsection{Academic and Pagan reception}

The second problem we are moving to now is a view on Pagan Theology from the perspective of the academia. While for some scholars Pagan Theology appears to be a legitimate concept, for others it is an attempt of some Pagans to act in the academia according to their personal interests instead of achieving academic goals and that such a behavior is dangerous for the academia.

Almost any criticism of Pagan Theology including those of Davidsen is resting on two beliefs: first, that those who criticize knows exactly what is it to be "academic" (or even "scientific") in the study of religion, and second, that his or her Weltanschauung produces perfectly adequate and neutral image of the object studied. As far as in European Religious Studies scientism, empiricism and historicism were three forces which won the battle of research programmes, the most of the authors assume that this perspective and this methodology is the best, the perfect, clean and untouched by any distortion brought only by insider's perspective. It is regarded as given and obvious fact that "an objective study of religion" should be based on "critical-naturalist program" as Davidsen put it or "empiricism" in terms of W. Hanegraaff. So, every critical review or article on the topic is based on the same arguments: any research is compared with the "ideal type" of empirical/naturalistic/scientific research. If it does not fit in this standard, such research is usually stigmatized as "religionism" or "latent esotericism" and a reviewer can proudly say that he or she has done his or her job. On the other hand, those who try to protect Pagan Studies from unjust criticism usually share these believes too. Their answers are 
targeted to show that Pagan Studies complies with these standards of scientism, empiricism and historicism and do not analyze methodological assumptions at the heart of the criticism. Instead, they are playing in an empiricist's game on the empiricist's field with empiricist's rules and concentrating around particular mistakes in critical articles.

However, why should one really be bothered if some research is not created in accordance with the ideal type chosen by a group of scholars? As far as Davidsen begins his essay with a statement that religionism was criticized as "ideology" "resting on theological or esoteric suppositions" (Davidsen, 2012), one can say the same about "naturalism" or "scientism" that was widely and soundly criticized as a form of dogmatism in number of publications from those of $P$. Feyerabend to recent anthology Scientism: the New Orthodoxy (Williams, Robinson, 2015). Speaking about Religious or Esoteric Studies it is much more important, at least for me, if a research can bring new perspectives and deeper understanding of the subject or not. I do not interested if it fits in some artificial standards, artificial "ideal types" of academic activity. I believe that in the academia many approaches to the same problem can and should coexist at the same time. These approaches can fight with each other, can criticize each other, but only together they will bring us new perspectives and more holistic view on the subject. The concurrence of different research programmes for me is a very important indicator of healthy situation in the academia. The problem begins when one programme wins and achieve almost unlimited power through institutional control. Winners can impose their approach to other scholars and try to monopolize the field which is an example of monopolism and a kind of totalitarian regime not in economics or politics but in the academia. One can ask is it appropriate not only from the point of view of the academia, but also from the point of view of democratic principles grounding the Western society in general. Thus, I do not believe that academic studies is a line of "paradigms" where better one comes after worse repeatedly and where only one point of view can exist. For me it is rather a field of battle between different research programmes in the sense of Imre Lakatos, programmes with different perspectives and different theoretical foundations. If we look from this perspective, we should agree that empiricist perspective is rather new research programme that is not the only option in Religious Studies either historically or geographically.

If we look at the Pagan Theology from this point of view, we can agree that Pagan Theology is an interesting research programme targeted to find, describe and systematize beliefs that a common for Pagans from different ages and countries. Whether this programme will succeed or not, I do not know, but we obviously can give it a chance and see what will happen. Even if it fails, we will get some new ideas, information and inspiration that maybe helps us to improve our understanding of Paganism.

However, not only academic but also insider's reflections on this topic are very ambiguous. While some Pagans welcome this concept as a new view on Paganism and an important step in the development of the Pagan community, others are very critical about it, describing it as dogmatic, overgeneralizing and ecumenist approach that is not suitable for Paganism. This discussion reflects the difference in the understanding of Paganism itself that exists among Pagans. Some Pagans are inspired with the idea of bringing some rational elements and critical thinking into their Pagan activities. These Pagans are often academically trained people who think that their historical, psychological or philosophical knowledge can help them to be better Pagans. On the other hand, there is another type of Pagans. These Pagans stress the role of feelings, of direct experience and intuition in Pagan activities. This type of Pagans describes a systematization of teaching as a limitation of their creativity.

Even the most liberal Pagans need to describe what Paganism is and therefore they need to choose some important aspects of Paganism and concentrate on them. Therefore, they do exactly the same thing as M. York and just do not call it Pagan Theology. For example, some authors can write about Pagan philosophy when they describe common aspects of Pagan mentality (Sythove, 2010), and it looks fairly similar to Yorks's idea of Pagan Theology. Such projects can be more or less inclusive and imply more or less generalized image of Paganism. York, for instance, uses a very broad definition of Paganism and describes it as a religion where "the two-way relationship that any person or community has with the physical world, with other humans or conscious beings, and/or with the supernatural, or magical dimensions of reality are to be conceived as a sacred, holy, or holistic relationship" (York, 2003). York contrasts Paganism with "Gnosticism" that is another "ideal type" of Theology in York's book. An opposition here is related to an attitude towards to the natural reality: while "Gnostic" religions describes it as an illusion, Paganism is concentrated on the importance of both natural and supernatural realms as well as their interactions.

Although this idea is rather interesting and can provoke discussions about an influence of Pagan ideas on different types of Weltanschauung, including Christianity and Atheism, such a broad definition was criticized both by a number of Pagans and by a number of scholars as an overgeneralization. However, it does not mean that its critics believe that we entirely cannot analyze and describe the common aspects of Pagan behavior, and discussions here are generally about the terms that are in use. For many Pagans, the word "Theology" has strong connotations with Christianity and religious dogmatism. Nevertheless, if there were no common beliefs shared by all Pagans, we could not talk about "Paganism" at 
all. Any definition requires a set of attributes. When it comes to a Weltanschauung, these attributes usually related to common beliefs and/or common behavior. A selection of these attributes, their description and systematization is what $\mathrm{M}$. York calls Pagan Theology. Therefore, if we believe that "Paganism" really exists and that this term is not a useless overgeneralization, we should agree that Pagan Theology in terms of York is a possible project. Otherwise, we should, first of all, abandon the term itself as well as the idea of Pagan Studies.

\section{Conclusion}

Keeping all that was said above in mind, I believe that the emergence of Pagan Theology is not a matter of chance, but a necessary stage of development, both in the conceptualization of contemporary Paganism itself and in Pagan Studies at the same time. An emergence of Pagan Theology reflects tendencies that one have been observing in these groups for years and that is why we cannot describe it as artificial phenomenon. It looks like Pagan Theology as a specific research programme has emerged in Great Britain and in the USA, and not without reasons. However, nowadays this concept achieves more popularity in other countries too, and I believe that it is reflecting the contemporary situation in the development of Paganism.

From the point of view of the academia, Pagan Theology can be described in three ways: as a research programme in Religious or Pagan Studies, as an independent field like Christian Theology and as a profession that can be a subject of professional training in educational institutions.

\section{References}

Davidsen M. A. (2012). What is Wrong with Pagan Studies? Method and Theory in the Study of Religion, 24: 183-199.

Hanegraaff W. J. (2012) Western Esotericism: The Next Generation. Mystic and Esoteric Movements in Theory and Practice. History and Discourse: Historical and Philosophical Aspects of the Study of Esotericism and Mysticism. St. Petersburg: Russian Christian Academy for Humanities. Pp. 113-129.

Kraemer C. H. (2012). Seeking the Mystery: An Introduction to Pagan Theologies. Englewood: Patheos Press.

Pitzl-Waters J. (2013) Pagans Studied: The 2013 Conference on Current Pagan Studies. [Online] Availble: http://wildhunt.org/tag/paganstudies-conference (February 22, 2015).

Phenomenology of Religion (2006). Britannica Encyclopedia of World Religions. Chicago: Encyclopaedia Britannica, Inc. P. 916.

Questions and Answers (2012). Questions and Answers about Paganism (in Russian). [Online] Availble: http://bujan.ru/molva/st2.html (February 22, 2015).

Rybakov B. A. (1980). Paganism of Ancient Slavs (in Russian). Moscow: Nauka.

Rybakov B. A. (1987). Paganism of Ancient Rus' (in Russian). Moscow: Nauka.

Sythove M. (2010). Beyond the Broomstick. Whyte Track.

Thorndike L. (1923). A History of Magic and Experimental Science. Vol. 1. New York: Columbia University Press.

White E. D. (2012). In Defense of Pagan Studies: a Response to Davidsen's Critique. Pomegranate: The International Journal of Pagan Studies, 14(1): 5-21.

Williams R. N., Robinson D. N., eds. (2015) Scientism: the New Orthodoxy. London: Bloomsbury.

Yates F. A. (1964). Giordano Bruno and the Hermetic Tradition. Chicago: University of Chicago Press.

York M. (2013). An Intersubjective Critique of A Critique of Pagan Scholarship. Pomegranate: The International Journal of Pagan Studies, 15(1-2): 136-150.

York M. (2003). Pagan Theology: Paganism as a World Religion. New York: New York University Press. 